\title{
8
}

\section{Vietnamese jurisprudence: informing court reform}

\author{
Pip Nicholson
}

In April 2002 the Communist Party of Vietnam (CPV) finalised its Resolution of the Political Bureau on Forthcoming Principal Judiciary Tasks ('Resolution 8'), a policy paper identifying priorities for Vietnamese legal reform. Subsequently, the Vietnamese Party-state issued laws to reform the courts, responding specifically to the needs identified in Resolution $8 .{ }^{1}$ The question emerging from this policy paper and the subsequent reforms is whether, or to what extent, this latest round of court reforms reflects contemporary Vietnamese theorising on the role and function of law and the courts.

At the heart of this question hovers a larger question. In its transition from a planned economy to a socialist-oriented market economy, the Vietnamese Partystate appears relatively certain about the nature of mixed market economy it envisions and seeks. While not abandoning the role of the state, the Vietnamese Party-state seeks to enable a mixed market-public sector economy (Van Arkadie and Mallon 2003). This requires a radical reduction in the role of the state in terms of market planning, production and employment and the take-up of production and employment by the private sector (Fforde and Vylder 1996; Beresford 1997).

It is not clear that the same vision exists with regard to the shape and form of the Vietnamese legal system, which is apparently radically changing to accommodate the changing economic conditions. While the economic base changes, it is suggested that the Party-state has not yet articulated an equivalently detailed vision for the form or shape of the transitional legal system. This chapter aims to explore whether a role for the courts has been articulated and whether the reforms reflect this.

This chapter does not consider the question of whether transitional legal systems will inevitably emerge as systems committed to the Anglo-European US liberal legal 
order. The story of Vietnamese legal reform in the context of global harmonisation debates is another tale. Instead, it focuses on the question of what, if any, role and place has been ascribed to the courts in the transitional Vietnamese state. In particular, is it that the courts will be theorised as continuing instruments of the Party-state or will they be increasingly positioned as independent of Party and/or state mechanisms?

Finally, in discussing legal reform and legal theory it is important to note that they are not causally connected; that is, legal theory does not necessarily inform legal reform or vice versa. Instead, it is perhaps better to understand the exchange between legal theory and legal reform as a dialogue. Further, legal reform may anticipate change and document past changes. By analogy, Vietnamese constitutional reform is thought often to reflect underlying changes already given effect and to foreshadow changes not yet implemented (Vu Dinh Hoe 1995).

\section{RESOLUTION 8}

Resolution 8 of the Central Executive Committee of the Communist Party of Vietnam released on 2 January 2002 needs to be understood, not as the blueprint for law reform, but as the first step in the process of developing a blueprint for law reforms across Vietnamese legal institutions. ${ }^{2}$ Resolution 8 provides insight into the direction of legal reform and how challenges are to be addressed. It should, however, be read as a work in progress rather than firmly establishing the trajectory of law reforms.

Further, it is very important to clarify terminology. Resolution 8 reflects upon and prescribes changes for 'cong tac tu phap', usually translated as 'judicial work'. In the Vietnamese context a reference to 'judicial work' is a reference not only to the work of judges and court staff, but also to the work of all organs that feed into the courts. Therefore, for example, the work of the procuracy (kiem sat), police (cong an) and investigators (canh sat) all falls within the Vietnamese term 'judicial work'. It could perhaps be better translated as 'justice work', but that is not the term ordinarily used. To avoid confusion, where the term 'cong tac tu phap' is used, it will be translated as 'court-related work'. This distinction is adopted to identify when a reform targets the courts and when it is pitched more generally to court-related bodies. ${ }^{3}$

Resolution 8 commences with a sustained critique of court-related work. ${ }^{4}$ It argues that court-related institutions have historically failed the community by making 'unfair judgments' (particularly of innocent people), failing to convict criminals, and generally reducing the trust of the people in courts and the Party. Further, it is implicit that the courts have also, at least partly, failed the Party, where they fail to implement the Party line. Following this frank general condemnation of the courts and court-related institutions, the Resolution proceeds to make five particular criticisms of the Vietnamese legal system. Briefly, these criticisms are that

- there are insufficient judges. Further, the judiciary is morally weak, lacks courage and is technically poorly trained 
- there remains a lack of uniformity in the organisation and perceptions of the function and responsibilities within court-related agencies and institutions are unclear (although this has somewhat improved recently)

- the working conditions (including salaries) within court-related agencies and institutions are very poor. In particular, District Court judges have poor working conditions ${ }^{5}$

- the laws relating to the court-related agencies and institutions are fragmented, inconsistent and incomplete and need to be reworked. Further, dissemination and education concerning relevant laws needs to be improved

- The government and the Party remain insufficiently involved in the theoretical research and practical performance of the court-related agencies and institutions.

Following this robust self-criticism by the Party-state of its court-related agencies and institutions, including the court system, the policy paper establishes a 'Directions' (quan diem chi dao) section, providing a framework or paradigm within which more detailed reforms are to be made.

The first comment made in Part A of the 'Directions' section of Resolution 8 explains that it is the role of the courts (and other agencies) to follow and implement Party policy. In particular, the court-related agencies must give effect to political tasks in the relevant period (cac nhiem vu chinh tri trong tung giai) and ensure the power of the state is united (bao dam quyen luc nha nuoc la thong nhat doan). In addition to being charged to give effect to the Party line, all court-related institutions are required to implement legislative, executive and judicial instructions. This section concludes by reminding the reader that Vietnam is a socialist law-based state of the people, from the people and for the people (nha nuoc phap quyen xa hoi chu nghia cua nhan dan, do nhan dan va vi nhan dan). Subsequently, this section calls for society to participate in court-related work. This appears to be an implicit restatement of a commitment to popular justice: a concept to which the Party officially committed in the mid 1950s when it embraced Soviet-style reforms to the existing 'bourgeois' legal system (Nicholson 2000).

The remainder of the 'Directions' section is less preoccupied with the broader role of court-related institutions and focuses on aspects of courts that need to be developed. For example, courts are to settle cases in a timely fashion, especially where serious criminal matters or offences against the state are involved, and there is a call for modernised, 'transparent', stable and 'strong' legal institutions.

Having set the framework for reform of court-related institutions, Resolution 8 proceeds to set out the mission or operational plan for these bodies (nhiem vu trong tam). This is the longest section of the policy, comprising eight parts, each of which proposes a specific reform. The proposed reforms reflect the critique of court-related agencies made at the outset of Resolution 8 and the general tenor of reforms set out in the 'Directions' section. 
The eight reforms to court-related work set out in Resolution 8, Part B, are ${ }^{6}$

- to enhance the quality and increase the responsibilities of those charged with implementing court-related work

- to give effect to Party policy on the reform (cu the hoa), organisation and renovation (doi moi) of court-related work

- to develop a transparent (trong sach), strong and stable (vung manh) courtrelated system

- to invest in the facilities necessary to enable completion of assigned tasks

- to enhance the ability of political organisations to oversee court-related work

- to increase the explanation of, instruction in, propaganda about, dissemination of, education in, and research about, law

- to strengthen international cooperation concerning court-related work

- to strengthen the leadership of the Party over court-related work.

Having set out the general parameters of Resolution 8, this chapter now identifies the extent to which each of the reforms affects the Vietnamese court system.

\section{Enhancing quality and responsibility for court-related work}

Section $\mathrm{B}(1)(\mathrm{C})$ of Resolution 8 charges the courts to guarantee citizens equal treatment before the law (deu binh dang truoc phap luat), real democracy (thuc su dan $c h u)^{7}$ and objective treatment (khac quan) (Resolution 8, section B(1)(C)). Further, it notes that judges and people's assessors must be independent and need only obey the law (Resolution 8, section $\mathrm{B}(1)(\mathrm{C}))$. Following this statement of the role and function of the courts, court personnel are instructed to determine cases on their merits in a timely manner after testing the evidence (Resolution 8 , section $\mathrm{B}(1)(\mathrm{C})$ ). To this end, the courts are instructed to enable the full participation of lawyers before trial, during collection of the evidence, and during hearings (Resolution 8 , section $\mathrm{B}(1)(\mathrm{Dz}))$. Further, courts are instructed to cooperate with other agencies to enhance the enforcement of judgments (Resolution 8 , section $\mathrm{B}(1)(\mathrm{E})$ ).

Section $\mathrm{B}(1)(\mathrm{dz})$ of Resolution 8 , addressing the hearing and determination of cases, is a request to court-related agencies to 'reconsider' the death penalty. In particular, the institutions are asked to investigate the possibility of restricting its use (Resolution 8, section B(1)(Dz)).

\section{Party policy on the reform, organisation and renovation of court-related work}

Section $\mathrm{B}(2)$ addresses concerns relating to the implementation of prior Party resolutions on court-related reform by targeting specific courts. In particular, the District Courts (Vietnam's lowest courts) are to be strengthened, an investigation into whether it is appropriate to expand the jurisdiction of the Administrative Court is proposed, and the possibility of establishing a family court is mooted (Resolution 8 , section $\mathrm{B}(2)(\mathrm{C}))$. 
Further, many reforms are directed at theSupreme People's Court, Vietnam's highest court. In particular, the Supreme People's Court is to manage the organisation of local courts and to supervise the professional development and the provision of guidelines to lower courts. Further, it is empowered to comment on the duties of court staff. The president is to appoint judges to the Supreme People's Court. By implication, the Supreme People's Court is to be given the power to appoint all judges of lower courts (Resolution 8 , section $\mathrm{B}(2)(\mathrm{C})$ ). This package of reforms suggests the repositioning of the courts to be less influenced and managed by the Ministry of Justice and president. Before the reforms giving effect to Resolution 8 were introduced, the Ministry of Justice determined the budget for the courts and the number of judges, and was at least partly responsible for judicial training. ${ }^{8}$ I have argued elsewhere that, when read together, the subsequent reforms implemented to give effect to Resolution 8 indicate a 'self-managing' court system (Nicholson and Nguyen Hung Quang, 2005).

\section{Developing a transparent, strong and stable legal system}

The third reform objective, set out in section $\mathrm{B}(3)$, calls for the development of 'transparent, strong and stable judicial personnel'. Also, all court-related agencies are called upon to increase the educational qualifications and political, moral and professional standards of their staff (Resolution 8, section $\mathrm{B}(2)(\mathrm{C})$ ). This section particularly seeks the promotion of candidates with appropriate political and moral fibre and seeks more transparent, timely and democratic appointment procedures (Resolution 8, section B(2)(C)).

This same section makes clear that the position of people's assessors (hoi tham nhan dan) or jurors should be investigated. In particular, Resolution 8 seeks review of the selection, role in court, training and management of jurors (Resolution 8 , section $\mathrm{B}(2)(\mathrm{C}))$. In effect, jurors' function is not to be taken for granted and is to be reappraised.

As a result of the generic nature of this document, in that it targets all courtrelated institutions and personnel, it is hard at times to be sure that the reforms apply to courts. Section $\mathrm{B}(3)$ is particularly ambiguous because courts are never specifically identified in association with any of the posited reforms. For example, it is not clear whether the proposal for the rotation of staff applies to courts, nor is it clear that the call for the annual review of the work performance of court-related personnel applies to judges.

\section{Enhancing infrastructure}

Likewise, there is no particular mention of judges or courts in section $\mathrm{B}(4)$, which advocates the improvement of facilities and wages for court-related personnel (Resolution 8, section $\mathrm{B}(2)(\mathrm{C})$ ). It appears implicit that the general call for the completion of building works and the reappraisal of salaries and allowances applies to judges as much as other agencies such as the police but, again, they are not specifically mentioned. 


\section{Enhance participation in and oversight of court-related work}

Section 5 of Resolution 8 commences with a statement of the need to attract community support for reform. It then urges the National Assembly and local People's Councils to oversee the work of courts. In particular, the National Assembly and local People's Councils are to monitor the decision-making and enforcement of judgments and to supervise the development of normative legal documents by court-related agencies (Resolution 8, section $\mathrm{B}(2)(\mathrm{C})$ ). It is not made clear to what extent these bodies would oversee the development of case notes and jurisprudence affecting courts (Luu Tien Dung 2003). ${ }^{9}$

In addition, section $\mathrm{B}(5)$ recommends development of the existing alternative dispute resolution mechanisms. In particular, it advocates that mediation and arbitration be adopted in the hope that fostering these alternatives will reduce the burden on courts and promote the prompt resolution of disputes.

\section{Increase the explanation of, instruction in, propaganda about, dissemination of, education in and research about law}

Section B(6) identifies the need to reform the laws on procedure and enforcement of judgments, recommending research, explanation and education relevant to courtrelated services. The Party urges an increase in the number of mobile hearings to maximise the flow of information concerning courts (Resolution 8 , section $\mathrm{B}(6)$ ). There is little else in this section that directly touches on the role of courts. However, it is again implicit that the courts would be caught by a general policy preference for greater legal propaganda and that they would be expected to contribute to this.

\section{Strengthen international cooperation}

The penultimate section $\mathrm{B}(7)$ of the policy paper seeks the strengthening of international cooperation by all court-related bodies, and various issues are identified for additional research. Of particular interest is the Party's request for comparative research that considers the question of the sovereignty and security of Vietnam and, by implication, its court system. The Resolution also advocates comparative research on training and crime prevention.

\section{Strengthen the leadership of the Party}

The final section of the operational plan (section $\mathrm{B}(8)$ ) restates that the Party 'shall lead' (lanh dao) all court-related agencies. In particular, three main areas are identified for Party leadership: politics, organisation and personnel. The posited aim in this regard is to ensure compliance with the Party's policies and state laws. It is also noted that Party membership should be increased and that courts should 'use the correct employees'. It appears that the Party is here urging the maximum use of Party members in court-related agencies, including courts. 


\section{Reading the reforms together}

It is hard to know whether any significance should be attached to the order of these reforms. They appear to move from the legally-specific to the contextual. I do not think they should be read as indicating a lesser role for Party leadership simply because comments about this ongoing feature of Vietnamese court culture appear at the end. Rather, this may fall at the end of the section on reforms as it is merely a restatement of the points made in the prior 'Directions' section of the Policy Paper.

\section{Implementation}

Part III of Resolution 8 provides an implementation plan. In broad terms, this seeks to centralise the implementation of this Resolution and to enable various stakeholders to contribute. In particular, the leadership of Communist Party committees in each of the Supreme People's Procuracy, Supreme People's Court, Ministry of Justice, Police, Military and Commission on Internal Affairs of the CPV are called upon to assist.

\section{The policy summarised}

In summary, Resolution 8 reiterates the leading role of the Party in court-related work. This is stressed both at the beginning of the policy paper and at its conclusion. Yet within this overarching statement, it is also said that citizens should be treated equally by courts and judges and that people's assessors are to be independent and subject only to law. The Resolution also requires the National Assembly and People's Councils to oversee the work of court-related agencies. In this way, the policy seeks to balance the role of the Party, the state and its laws, and the public or society.

Moving from the general to the particular, the policy paper canvasses various specific reforms. It requires that the lowest and highest courts within the Vietnamese court hierarchy, the District and Supreme People's Court respectively, be strengthened. It urges legal institutions to circulate information about their work more widely and, in particular, to make greater use of mobile courts. It also calls for the greater use of mediation and arbitration to resolve disputes.

In terms of personnel, Resolution 8 calls for the appointment of better-educated staff with good ethical and political credentials. By implication, these appointees are also to be Party members or, at the very least, endorsed by the Party. The policy paper also seeks greater transparency in the appointments process and an increased role for the Supreme People's Court in court appointments and management. Following the Resolution, the president is only to appoint judges to the Supreme People's Court, with the Chief Justice of the Supreme People's Court now appointing all other judges, albeit with local agencies playing a large consultative role. Salaries and working conditions are also to be enhanced.

Finally, the Resolution seeks investigation of

- the role of the people's assessors

- the possibility of a family court 
- the possibility of expanding the jurisdiction of the Administrative Court

- the possibility of limiting the death penalty

- comparative research on the role and place of courts in terms of state sovereignty.

\section{INTERPRETING RESOLUTION 8}

As noted above, not all reforms outlined in Resolution 8 necessarily target the courts. ${ }^{10}$ Therefore, to assist with interpreting Resolution 8 in this context, it is necessary to see where those reforms targetting courts have been implemented in the subsequent legislative package introducing court reforms. ${ }^{11} \mathrm{~A}$ brief consideration of the key features of the legislation affecting courts is set out below to give some insight into how the Party-state has interpreted its own policy recommendations.

The core features of legislation affecting people's courts introduced in the 2002 Law on the Organisation of People's Courts are that

- judges must have a Bachelor of Laws Degree, have attended adjudication training, and have had legal experience (Article 37).

- with the exception of the Chief Justice and judges of the Supreme People's Court, all appointments, removals and dismissals of judges to provincial and district courts will be made by the Chief Justice of the Supreme People's Court on the advice of especially constituted Judicial Selection Councils. Appointment, removal and dismissal of Chief Justices and Deputy-Chief Justices of provincial and district courts will be by the Chief Justice of the Supreme People's Court, acting on the advice of the relevant People's Council (Articles 25 and 40).

- there will no longer be a Supreme People's Court Justice Committee (Article 24).

- people's assessors will be elected by local People's Councils on the recommendation of the relevant Fatherland Front organisation (Article 41).

- people's assessors can be dismissed by the Chief Justice of the court to which they have been elected with the agreement of the relevant Fatherland Front committee (Article 41).

- the Standing Committee of the National Assembly will determine court budgets acting on the advice of the Chief Justice of the Supreme People's Court (Article 44).

- the number of judges and people's assessors will be determined by the Standing Committee of the National Assembly on the advice of the Chief Justice (Article 42(1)).

- the Supreme People's Court, in conjunction with local people's councils, will be responsible for the management of local People's Courts (Article 17).

- the need to develop information technology to help the courts do their work is explicitly recognised (Article 46). 
The specific recommendations made in Resolution 8 have been taken up by the 2002 Law on the Organisation of People's Courts. ${ }^{12}$ While the list of amendments looks very impressive, I have argued elsewhere that in some respects the changes are more apparent than real. ${ }^{13}$ For example, the Chief Justice's new powers to appoint judges to lower courts do not decrease the Party's grip on judicial appointments (Nicholson and Nguyen Hung Quang, 2005). In particular, candidates for judgeships still have to produce a letter in support from the Chief Judge and the Head of Organisation and Personnel of the Provincial People's Court of the province to which they apply..$^{14}$ If they apply to a district court, support for the appointment needs to be supplied by the relevant Provincial People's Court. Further, candidates need to demonstrate that they have a political theory diploma. ${ }^{15}$

This, however, is not a story of court reform but a story of the intersections and conflicts between the role and place ascribed to law and the role of the courts in transitional Vietnam. It is therefore not necessary here to examine in detail the features of the recently legislated reforms (Nicholson 2003). The question remaining for this part of the chapter is to characterise the nature of the court's role as it is set out in Resolution 8 and then see to what extent this diverges from, or is reflective of, the role ascribed to law in contemporary Vietnam.

One of the most interesting aspects of Resolution 8 is the tension around the Party-court relationship. On the one hand, the courts are explicitly under the Party's leadership including by virtue of the fact that appointments to the courts ought to be Party members with demonstrated political credentials (Nicholson and Nguyen Hung Quang, 2005).${ }^{16}$ On the other hand, courts are to be independent and obey only the law. How can these apparently contradictory statements be reconciled?

If one reads this from a Western perspective imbued with notions of judicial independence, it is not possible to reconcile the policies. The courts as described are intended to enable Party policy, with the judiciary and court personnel being members of the Party. Concurrently, these political functionaries are to be officers of the court, whose role is to enforce only the law. To those schooled in the requirement that judges have no allegiance other than to the law and the fair determination of disputes before them, free from interference from any other party, body or individual, this dual loyalty required of Vietnamese judges is not tenable.

This raises the question 'what is "law" in Vietnam?' In socialist states, law is traditionally seen instrumentally - it is the force that gives effect to Party policy, whether that be through a legal instrument or policy. One of the best characterisations of Vietnamese law offered by a Western researcher describes it as follows

the underlying notion of law is not so much that of an immutable order to which all should bow, but rather that of an important element of the way in which the Party line is implemented (Fforde 1986:62).

This matter is taken up in greater detail below, but for present purposes, law has to be seen as the Party line which may be (and today, more often is) enacted via legal instruments passed by those with state legislative authority. 
One reconciliation of this apparent conflict is to see courts as independent of Party interference, but not of Party influence (Gillespie 2003). Put another way, courts are to be guided by Party policy and to see its implementation as one of their objectives, but Party members ought not influence particular proceedings.

Under this approach, courts can concurrently be bound by law and receive Party guidance, particularly if it is accepted that guidance from the Party assists with the interpretation of laws. Many Vietnamese laws are expressed in general terms only and their interpretation is open. The Party can then illuminate and explain how laws are to be implemented. For example, Article 37 of the Law on the Organisation of People's Courts sets out that

Vietnamese citizens who are loyal to the Fatherland and the Constitution of the Socialist
Republic of Vietnam, who have good qualities and virtue, are incorrupt and honest,
determined to protect the socialist legislation, have the Bachelor of Laws Degree and have
been trained in adjudicating operations, have engaged in practical work for a period of
time prescribed by law, have adjudicating capability and have good health to ensure the
fulfilment of assigned tasks may be selected and appointed to work as judges. ${ }^{17}$

In this list of attributes required of judges, there are various undefined and imprecise terms. Just to take two examples, it is not clear how 'loyalty to the Fatherland and the Constitution' is to be interpreted, nor how 'adjudicating capability' is to be construed.

Various commentators have suggested how they ought to be read. For example, in relation to 'adjudicating capability', the Chief Justice of the Hanoi People's Court has written that those who have completed a course at the Legal Professional Training School have the requisite judicial capacity. Further, he has also suggested that judicial capacity should be interpreted to mean a preference for mature or older candidates (Nguyen Van Hien 2001). We see that a senior judicial officer explains how these criteria are to be interpreted; presumably because he is empowered, as a senior judge, to speak both on behalf of the court and also on behalf of the Party. Yet this is not the final word on this point. The Party retains the right to clarify this at any time in a variety of ways-for example, by policy statement endorsing a circular between courts, or more informally through consultation with senior Party figures from the courts, the National Assembly or the Party itself.

A further tension evident in Resolution 8 surrounds the balancing of individual and collective rights. Resolution 8 exhorts the courts to treat all persons equally (Resolution 8 , section $\mathrm{B}(1)(\mathrm{C})$ ). On the face of it, this is a call for equal treatment by the courts of all people before it and could form the basis of an argument that individual litigants have rights equal to those of the state or the collective. This echoes the 1992 Constitution, which provides that 'all Vietnamese citizens are equal before the law' (Article 7). Concurrently the judiciary is instructed to follow Party leadership and is reminded that it is subject to the 'supervision' of local democratic institutions such as People's Committees and, in the case of the Supreme People's Court, the National Assembly. Accountability to the National Assembly is also constitutionally enshrined (Article 135, 1992 Constitution). 
Again this tension needs to be contextualised. In practice, this reference to equal treatment can not be read as a statement of the individual rights of claimants or defendants, but a statement that all those before the courts ought to be judged by the same policies and laws. ${ }^{18}$ That is, this statement cannot be read as abandoning the value placed on the collective interest in the Vietnamese context, but must be interpreted to say that those in proceedings before a court must be equally subject to the same sets of values, policies and laws. Again, what is being set out is not that courts will only be bound by law, but that courts should be consistent in their evaluation of cases which in turn requires consistency in understanding laws and the direction of Party leadership.

Resolution 8 also calls for greater community knowledge of court work. To this end, one concrete proposal is that courts should increase the number of mobile hearings (Resolution 8 , section $\mathrm{B}(6)) .{ }^{19}$ While this may increase the public scrutiny of hearings, it will not enable the public to understand how cases are decided. Although Resolution 8 calls for the formation of normative legal documents, it does not make any specific recommendation with respect to that process.

Court judgments have not to date been a great source of normative legal principles. As with many civil law systems, why it is that a particular case is determined in a particular way is not evident from the written record. Further, judgments are not publicly available. For example, in criminal cases, judgments record the names and background of the parties, the charges and whether they have been found guilty. ${ }^{20}$ The evidentiary basis for the conviction is not recorded..$^{21}$ When explaining sentencing, the judgments include an analysis of the moral and political credentials of those being tried, explicitly linking these to the imposition of lenient or harsh penalties. ${ }^{22}$ It is not clear from Resolution 8 how the balance between increasing the role of law and maintaining popular justice is to be achieved. ${ }^{23}$

Finally, Resolution 8 appears to promote the role of lawyers (both advocates and prosecutors). It instructs judges to enable lawyers to participate fully in pre-trial and trial work (Resolution 8, section $\mathrm{B}(1)(\mathrm{C})$ ). How this would affect the outcome in a trial is not clear. It has been common practice in Vietnam for the procuracy to meet with the judges and determine the outcome of cases before trial. Enhancing the role of lawyers raises the possibility of the judge allowing more adversarial-style advocacy in court (ordinarily associated with the common law tradition). Further, it could indicate a shift from predetermined resolution of cases to testing the evidence before deciding the case..$^{24}$

Promoting the work of lawyers may suggest that the state seeks to foster public trust in the emerging court system by way of empowering the advocate. Just as Mark Sidel has noted that it is too simplistic to talk of Party instrumentalism in the context of Vietnam's constitutional reforms, it may be the case that the relatively greater role accorded to lawyers in court could produce tensions (even contests) about the proper resolution of cases and enable explicit or implicit criticism of Party policy in court (Sidel 2002). Thus the court (the Party-state) may eventually negotiate the outcome 
of cases with lawyers (many of whom are privately employed and not Party-state functionaries). ${ }^{25}$ This appears highly experimental in a state where the control of courts has, until recent times, been absolute.

It appears, therefore, that Resolution 8 opens up the possibility of quite radical legal change. Although it appears significant, the principle of court independence, mediated by Party leadership, is perhaps the least radical feature of this policy. The potentially more fundamental changes lie in the enhancement of the role of law and of the legal profession, including prosecutors. The Party-state may conceive that by retaining Party leadership of the institution, and particularly by reinforcing its tight control over the selection of personnel, changes to the primacy of law and the profession can be incrementally implemented. Alternatively these potentially radical changes might reflect either a new vision giving law a more central and stronger role in regulating social relations (but perhaps not state-society relations?) or simply an experimental phase exploring such possibilities.

\section{CONTEMPORARY VIETNAMESE DEBATES ABOUT THE ROLE AND PLACE OF LAW}

The question is then to what extent the changes introduced in Resolution 8 reflect a theorised understanding of law within Vietnam. This involves some exploration of the role and place of law in Vietnam generally and, more particularly, the role the courts play within any general conception of the role of law.

This part of the chapter will outline the key concepts used to describe the political and legal theories underpinning the Democratic Republic of Vietnam (1945-76) and the Socialist Republic of Vietnam (1976 to the present day). The core concepts introduced are 'democratic centralism', 'collective mastery', 'socialist legality' and 'rule-based state' (sometimes erroneously translated as rule of law). The role and place of socialist and revolutionary morality and how valuing moral precepts affects or interacts with the role and place of law is also briefly discussed. It will then be possible to revisit Resolution 8 and see how it reflects or diverges from established Vietnamese legal thinking.

The discussion is organised chronologically to reflect the emergence of Vietnamese legal theory and divided into the time periods: 1945-59, 1960-76 and 1986-2003. The period 1976-86 is not a particular focus as it can largely be viewed as a period of consolidation rather than change, with the North exporting its views and practices to the South of the country in post-unification Vietnam (Gillespie 2004). ${ }^{26}$

The role and place of Vietnamese law has been dynamic over time. Initially the communist state had a fairly instrumentalist view of law. Theorising was mainly political, looking at the role of 'democratic centralism' (tap trung dan chu) and the role of law as an administrative mechanism, coexisting with, but not binding, political leaders and policymakers. In the DRVN over the period 1960-76, socialist legality (nguyen tac phap che xa hoi chu nghia) gained increasing currency. In more recent times, and particularly since the 1991 Seventh Party Congress, the Party-state 
arguably has endorsed, while not clearly identifying the features of, a law-based state (nha nuoc phap quyen) and a socialist law-based state (nha nuoc phap quyen xa hoi chu nghia). The role of collective mastery (lam chu tap te) in the contemporary period is harder to isolate.

In the Vietnamese context it is not possible to talk of the state without talking about the Communist Party of Vietnam (Fall 1956; Huynh Kim Khanh 1982). The Party is at the epicentre of Vietnamese politics and remains responsible for the official enunciation and implementation of all policy changes. The Party dates back to the early 1930s, although it was officially disbanded between 1945-51 and renamed on several occasions, ultimately carrying the name the Communist Party of Vietnam (Dang Cong San Viet Nam) from 1976 (Weggel 1986). ${ }^{27}$ Between the 1930s and 1976 the personnel at meetings and congresses essentially remained the same, indicating that, whatever the appellation, the core group of leaders who identified with the original Indochinese Communist Party continued at the helm until unification (Klein and Weiner 1959). Thayer has commented on the increasing trend of younger and better-educated Party members in the National Assembly, but while new figures are emerging within state institutions, continuity with the past remains (Thayer 2002).

Through its extensive nomenklatura system, the contemporary Communist Party of Vietnam continues to ensure that all significant office holders of the state are Party members (Gillespie 2002). For example, 90 per cent of judges are said to be Party members (Nicholson and Nguyen Hung Quang, 2005). Similarly, Thayer estimates that the current National Assembly comprises around 90 per cent Party members (Thayer 2002). It is not possible to separate the Party from the state. State functionaries are Party members, and as a consequence bear all the obligations that membership of the Party involves. ${ }^{28}$ It is for this reason that the term Party-state is used.

Although the Party-state is the dominant political force in Vietnam, it is an organisation where various political views are expressed and debated. For example, it is widely known that Party members have preferences ranging from transition to a multi-party state to retaining strong one-Party leadership. ${ }^{29}$

While Vietnamese jurisprudence is closely linked to that of the old Soviet Union and arguably not isolated from that of the People's Republic of China, it is not a replica of either. ${ }^{30}$ From 1945 to the early 1970s, Vietnam was most influenced by Soviet jurisprudence (Nicholson 2000). In more recent times, while the extent to which the Chinese and Vietnamese converse about legal theory remains unclear, it is known that exchanges occur (Sidel 1998).

\section{Morality and law}

Much has been written about the marginal role of law in Vietnam (Sidel 1997; Gillespie 2001a; Nicholson 2000). Broadly speaking the argument is that custom and morality (Confucian and Socialist ${ }^{31}$ played a major role in shaping Vietnamese social mores and that law existed largely as a punitive instrument of the state, rather than as the basis for social interaction. This chapter does not address the question of whether law is more relevant in contemporary Vietnam. This is a subject for another 
study. Yet the fundamental significance of morality is raised to protect against any misconception that the role of law has changed to such an extent that morality is no longer relevant. Without significant studies of legal consciousness this matter cannot be resolved, but studies among local Vietnamese businesses indicate that the relevance of law remains marginal (Bergling 1999; McMillan and Woodruff 1999).

\section{Early days: war and legal instrumentalism}

Between 1945 and the late 1950s, during which period the DRVN defeated the French and the country was partitioned, the role and place of law was contested..$^{32}$ Arguably, Ho Chi Minh never anticipated governing without the assistance of law. ${ }^{33}$ He wrote of the excesses of colonial court systems (Ho Chi Minh 1961:96-102), but did not foreshadow a society without law or legal institutions (Nguyen Ngoc Minh 1985). Ho Chi Minh argued convincingly that the French were able to maintain one law for the Vietnamese and another for their own subjects (Hooker 1978). Ho's trenchant criticisms of the French administration of justice, which describe the scales of justice being permanently skewed against the local population of Vietnam, was not a critique of law in general (Ho Chi Minh 1961). ${ }^{34}$

Lawyers debated the uses to which the new DRVN government put law and legal institutions (Sidel 1997a). These discussions were at their most divided and outspoken during the publication and then banning of the Nhan Van (Humanity) and Giai Pham (Beautiful Literary Work/Masterpiece) periodicals. These two publications were circulated in 1956 and contained some extremely direct critiques of the uses to which law had been put by the Viet Minh leadership. For example, three categories of critique were undertaken by Nhan Van: freedom and democracy; legality, human rights and the strengthening of institutions; and opening up all legal thought and research (Boudarel 1990). Those that spoke out on these issues did so without circumlocution or delicacy, as demonstrated by the following passage.

It is the absence of legislation that favours abuse of power and authoritarianism (Boudarel 1990:165-6). ${ }^{35}$

This extract is taken from an article dealing with the errors of the land reform campaign $^{36}$ and the 'contempt for legality' prevailing, so it was argued, in Vietnam at this time (Boudarel 1990).

The government was exhorted to put a stop to these expressions of dissent; the request that the publications be closed down was printed in the official newspaper.

We demand that the authorities take definite measures against Nhan Van. The souls of the young students are still as pure as a white page inscribed with beautifully bright pictures of our regime, our future and our happiness. We want to be given healthy thoughts and are determined to oppose anything which stands in the way of our advancing steps. ${ }^{37}$

By 1960, the Party had closed down the publications and a series of trials ensured that the major players were incarcerated (Boudarel 1990). ${ }^{38}$ 
The organisational basis of the DRVN shortly after the revolution is perhaps best described by the term 'democratic centralism' ${ }^{39}$ When describing the features of the newly introduced Vietnam Workers' Party in 1951, Ho Chi Minh wrote 'As regards its organisation, it adopts the system of democratic centralism' (Ho Chi Minh 1994:127). In short, democratic centralism in Vietnam meant that all office holders and Party representatives were elected and each organisation was accountable to the higher equivalent body..$^{40}$ For example, a District People's Committee was responsible to a Provincial People's Committee and a local court was accountable to the next highest court. Ultimately most organisations were accountable to the Party via the National Assembly, Ministries or the Party committees at local and regional levels. ${ }^{41}$ It was only through such accountability and central control (also referred to as 'iron discipline') (Ho Chi Minh 1994:127) ${ }^{42}$ that the Party could hope to enforce its policies effectively. This approach was justified on the basis that it enabled grassroots involvement (through election) in the democratic process, ${ }^{43}$ but also that once the 'correct' policy had been determined (one that benefited the 'masses' $)^{44}$ implementation would be centrally coordinated. Failure to implement according to instruction carried with it censure (Truong Chinh 1994). In relation to the courts, this basic principle was an ideal to which the courts aspired, but implementation was problematic. As we shall see, democratic centralism has been retained as an organising principle to the present day.

The regime's supporters during the period 1945 to 1959 propounded an instrumentalist view of law without explicitly theorising about socialist legality (see below; and Sidel 1997a). ${ }^{45}$ No separate narrative emerges from the available sources for the period that explicitly relies on socialist legality to connect law, socialism and the new nation. ${ }^{46}$

The perception that law was more commonly viewed instrumentally rather than theoretically (except by its detractors) rests on several commentaries on Vietnamese legal development and the nature of the debates between intellectuals and Party figures over this period. For example, Nguyen Nhu Phat, a theorist with the Institute of State and Law, writes

\footnotetext{
The Communist Party of Vietnam is a political party which gained society's almost absolute confidence and is able to call on the support of all people. Moreover, in the first years of the people's democratic system, the distinction between the leadership of the Party and the administration of the state was out of the question because the state could not be present everywhere in the country and secret Party cells had to play the role of the state (Nguyen Nhu Phat 1997:398).
}

Nguyen Nhu Phat portrays Vietnamese law in the early period of the revolution as reflecting the domination of political expediency and practical considerations. In effect, the State Plan (or policies) was the law. Legal jurisprudence was relegated to a critique of practice (Nguyen Nhu Phat 1997). The Nhan Van/Giai Pham experience reinforces this perception. Not surprisingly, the socialist legal debates did not immediately take hold in war-torn Vietnam. 


\section{A unified DRVN: the policy-law dichotomy}

There was not one view of law between the defeat of the French in 1954 and unification of the country in 1976, but the outspokenness of the Nhan Van/Giai Pham period did not resurface (Nicholson 2000). The publications of the Supreme People's Court explicitly condemned it. ${ }^{47}$ Instead, this period witnessed the development of a legal studies group (to luat hoc) debating law. The legal studies group originally convened under the auspices of the Social Sciences Division of the State Sciences Committee, later forming the genesis of the Institute of State and Law (Sidel 1997a). According to Mark Sidel, this group, comprising scholars and non-communist intellectuals, included 'leading voices for legal reform' (Sidel 1997a:16). ${ }^{48}$

One of the key tensions for the emerging system of administration was the relationship between law and policy. All too often, policy was not enacted as law and yet Party-state officials were expected to implement both. Policy was at least as significant as luat (law) (Sidel 1997a). For example, law could be used interchangeably with policy (Le Duan 1994). ${ }^{49}$ As a result, the importance of policy (or the State Plan, as it was also referred to) cannot be underestimated. As we saw above, Fforde aptly characterises law as 'an important element' of the Party line, but it was not authoritative at this time (Fforde 1986:62).

Nguyen Nhu Phat expresses the view, in the context of economic contracts, that the State Plan operated as law when he writes

\footnotetext{
[i]n the old regime, planning was the main instrument used by the state to administer the national economy. That is to say that planning but not law was the main and most important factor. Planning would always prevail over law. Any conflict between the law and the planning would be resolved in 'favour' of the planning. Generally speaking the law was only a subsidiary instrument while the policy and resolutions passed by the Party, administrative commands and planning documents were the main instruments in governing economic activities (1997:398).
}

Yet there was debate about the application of policy that was intended to be law, but was not yet enacted. A Vietnamese lawyer writing in 1964 talked of the need to enforce laws, distinguishing them from policies.

The policies of the Party must go through a process of explanation and elucidation so that the people will understand them clearly, support them and by their self-awareness carry them out. These policies must also pass the National Assembly, the government Council and other government organs before being enacted into law and before being backed by the authority of the government (Truong Tan Phat 1964:2).

This more legalistic approach, requiring that policy be enacted as law in order to be enforceable, is rarely so clearly stated in major public speeches..$^{50}$ More commonly, the terms 'policy' and 'law' are used interchangeably or ambiguously (Sidel 1997a). ${ }^{51}$ For example, in this period the role of the Party was developed and entrenched via active promotion of its work and by training its members-a strengthening of the Party, as Truong Chinh (1994:605) described it when he wrote that '[i]n Party building we stress both ideological and organisational aspects'. In short, the Party aimed to raise the calibre of members through training. In 1968, all cadres were to be schooled in the 'four-good' principles. The second of the four tenets was 
[g]ood at helping the people in obeying the law and in the implementation of Party and state policies (Truong Chinh 1994:606). ${ }^{52}$

This statement suggests that policy, after it became law, was what the people had to obey. Yet both law and policy must be 'implemented'. Truong Chinh did not address the issue of whether policy and law were interchangeable or what happened if they differed.

Le Duan (1994:452) writes that

[f]ormerly the Party line and policies penetrated the masses and were implemented through propaganda and agitation work with regard to each person or each group. Today besides these methods which we must apply even more effectively, broadly and adequately, we must also use large-scale organised measures...This can be done only through state laws which reflect the interests and the will of the working people.

This statement, made in 1973, advocates the passage of policy into law. This approach is echoed in contemporary Vietnam. One typical call for a law-based state refers to earlier times when 'it seems that for a while we emphasised building a society by means of the "rule of morality" and thus somehow neglected the law' (Nguyen Nham 1997:3).

Despite a clearer articulation of how the emerging socialist state would be administered (democratic centralism with the Party at the epicentre of politics), the state's policy priorities were variously implemented via laws or policies or both. In effect, the debate about the role of law and policy continued, but law was not necessary to state-sanctioned decision-making (Sidel 1997a).

It is relevant here to consider how the Vietnamese courts themselves conceived their role. ${ }^{53}$ The Chief Judge, in an article summarising the Supreme People's Court's Five-Year Plan 1961-65, commenced by referring to the Third Communist Party Congress, held in September 1960. He noted the comments made at that Congress on the relationship between Party and state 'in the transitional stage towards socialism in the North' (Pham Van Bach 1961b:1). He argued that the Party's role in the leadership of the state was paramount

[t]o unite the entire people, bring into full play our people's ardent country-loving spirit, traditions of brave fighting and hard work, at the same time to reinforce the solidarity among the socialist countries headed by the Soviet Union, to create favourable conditions for the North to march speedily, strongly and firmly towards socialism, build a comfortable and happy life in the North and consolidate the North as a steady base for the struggle for the country's unification, thus making a contribution to strengthening the socialist camp and the defence of peace in Southeast Asia and the world (Pham Van Bach 1961b:1).

The Chief Judge reiterated the Third Party Congress' view that the People's Democratic Administration, of which the court was a part, must 'fulfil the historic task of the proletariat's dictatorship' and to that end implement socialist reformation in the areas of agriculture, industry, economic policy and cultural change (Pham Van Bach 1961b:1). Chief Judge Pham Van Bach pointed out that the 'position, role and political responsibilities of the People's Court are not separable from position, role and political and economic responsibilities of the People's Democratic State'. In turn the state's responsibilities were 'pointed out clearly in the political report of the Party Central Committee' (Pham Van Bach 1961b:2). Here the connection between 
Party and court is at its most clear. The Chief Judge has drawn the connections so that no reader could doubt that the role of the courts was, ultimately, to implement state policy.

Having outlined the court's political role the Chief Judge proceeded to connect the court's work with the five-year plan (Pham Van Bach 1961b). He urged the work of the court to assist the revolution; to defend the social order (which included economic policies); to educate the masses to fight against acts violating the law, policy and disciplines of the state; and to promote the people's democratic legality. This call to arms also stipulated that the role for the courts was to implement state policies as well as state laws (Pham Van Bach 1961b).

To implement the Party's policies effectively, court officials were told

[w] e must be fully aware of the role and effectiveness of the People's Court in contributing to the furtherance of the entire revolutionary work...apply properly the line and policy of the Party and state, always heighten the People's Court characteristic of true democracy, apply strict basic principles guiding the work of adjudication, organise trials according to the Law on the Organisation of People's Courts and ensure careful, correct and lawful adjudication which always enjoy sympathy and support of the people (Pham Van Bach 1961b:6).

Judges and assessors were thus instructed not only to apply state and Party policies, but also the Law on the Organisation of People's Courts when organising trials. This law set out the basic elements of a fair trial, the role of assessors and judges, and the meaning of an open court. The statement suggested that careful and correct adjudication required the judge and people's assessors to apply policies to produce lawful adjudication acceptable to the masses.

In summary, this publication explained to court officials that they had to implement state policies and rely on senior courts and training as the basis for understanding those policies. Pham Van Bach reiterated that officials must understand that their work was political and that both the Party and the community must endorse it. He sought to inspire pride in the work of the courts as institutions linked to the fortunes of the war-dominated country. The role of the Supreme People's Court was to show leadership, and in so doing, reflect the Party's policies.

Throughout the 1960s, a judicial conference was held annually to reinforce the duties and responsibilities of judges. The Supreme People's Court issued a report on the conference's conclusions. The issues raised in the Chief Judge's first FiveYear Plan for the courts, outlined above, were echoed over the years. The central political role of the courts was reiterated. ${ }^{54}$ It was the duty of the Supreme People's Court to foster the upholding of socialist legality by lower courts. ${ }^{55}$ However, it was pointed out that there was not always agreement among senior judges about what the law ought to say or, where it existed, how it ought to be interpreted. ${ }^{56}$

This exploration of the policy-law dichotomy in Vietnam is one way of unpacking what is meant by socialist legality. It demonstrates that law is not binding or immutable, but rather a support to, and manifestation of, the Party line. In particular, law does not override policy, but exists to give it effect. As an element of the Party line, law is therefore not binding on Party members who would have a better 
appreciation of the Party's intentions and how they should be implemented in particular settings. For example, a judge writing about how law and policy interacted explained,

At present the people's courts only apply the new laws of the people's power. In the event of there being no legislative text they follow the principle of analogy or simply the general political line of the revolution (Le Kim Que 1974:99).

In a similar vein, Gillespie explains that socialist legality characterises policy as the 'soul and spirit (linh hon) of the law' (Gillespie 2004:150). Further, Gillespie argues that socialist legality conflated legalism and 'state discipline ( $k y$ luat nha nuoc)' with the result that 'violations of the law were considered revolutionary betrayals' (Gillespie 2004:150).

From 1959 to 1976, a subtle change emerged. In effect, socialist conceptions of law were introduced and promoted. In particular, the Supreme People's Court articulated a clear commitment to socialism and socialist legality, which saw law as a vehicle for Party-state policies, inferior to the Party line where conflicts occurred. The press and the leadership criticised capitalist legal systems for working only to the advantage of the bourgeois classes. ${ }^{57}$ In Vietnam a socialist legal system was endorsed where law was neither independent of, nor binding on, the Party-state.

\section{Legal theory in the contemporary period}

Thus far we have seen the Party-state construct theories concerning the interaction of the Party and its laws and legal institutions (socialist legality) and the mechanism by which all organisations are to be held accountable to, and led by, central Party institutions (democratic centralism). What remains unexplored is theory indicating the Party's relationship with the people. ${ }^{58}$

Through the revolutionary period the Party-state positioned itself as giving effect to the 'mass' line. ${ }^{59}$ Its leadership was 'of the people, from the people and for the people' (nha nuoc phap quyen xa hoi chu nghia cua nhan dan, do nhan dan va vi nhan dan). This principle of Party leadership giving effect to the will of the people is captured in the two DRVN constitutions of 1945 and 1959 and their two SRVN successors of 1980 and 1992. ${ }^{60}$ However, the principle of 'collective mastery' (lam chu tap the) was not articulated as a concept until the 'euphoria surrounding reunification in $19755^{\prime}{ }^{61}$ Gillespie argues that at this time the state explicitly acknowledged the 'mastery' of the working peoples, and posited the interests of the state and individual as one-the political leadership existing to reflect and enable the worker-peasant alliance. ${ }^{62}$

As Gillespie notes, the classless society envisioned by Vietnamese collective mastery is predicated upon social harmony and group effort. In presenting it this way, the doctrine removes private 'space' for talk and debate outside the statesanctioned domains of collectives and state bureaucracies. Further, Gillespie notes that the doctrine was 'hostile to private legal rights' (Gillespie, Chapter 3). How the doctrine accommodates the transition from socialist legality to law-based state (set out below) remains unclear. 
In 1991, the Seventh Party Congress of the Communist Party of Vietnam adopted 'nha nuoc phap quyen', variously translated as 'state-legal-rights' or 'law-based state'. As Gillespie points out, this is a Vietnamese adoption of the Russian concept 'pravovoe gosudarstvo', in turn reflecting the German principle of 'Rechtsstaat' (Gillespie, Chapter 3). In each case, the principle has the 'state posited as the highest, if not the only source of law' (Gillespie, Chapter 3). In the Vietnamese context, nha nuoc phap quyen means that the state will not only be the source of law but also be bound by law. This was the basis of the very fundamental constitutional changes made in 1992, which saw the introduction of an amended Article 4 to include a statement requiring Party members to be bound by the law. ${ }^{63}$

The introduction of 'law-based state' as a conceptual basis for the place and role of law in contemporary Vietnam has not replaced socialist legality as the current orthodoxy. Instead, the two concepts of law coexist and fuse to produce 'socialist law-based state' (nha nuoc phap quyen xa hoi chu nghia) (Gillespie 2004:152). Two issues emerge. What is meant by the state in this context? Further, to what does the term 'law-based' refer?

As we have seen, it was not possible to conceive of the Vietnamese state without admitting the leadership of the Party, which remains the situation today. For example, the most recent round of constitutional amendments did not change the leadership role ascribed to the Party in $1992 .{ }^{64}$ Resolution 8 also restates the Party's leadership role.

The extent and limits of the term 'law-based' are less clear. One view is that the Vietnamese Party-state has repositioned law as the 'highest', if not ultimately the sole source of, binding instrument. This view is supported by the fact that the Party, through the Constitution, is said to be bound by law. ${ }^{65}$ More particularly, it envisions law ultimately becoming superior to policy. ${ }^{66}$ Yet as a matter of practice law remains subordinate to Party policy, particularly given the reliance on policy to interpret law.

\section{Socialist legality and law-based state compared}

Table 8.1 summarises, albeit briefly, the similarities and differences between socialist legality and the law-based state at a broad conceptual level. In an attempt not to confine the comparison to Western liberal notions of law, a range of indicators have been listed to tease out what each of the concepts reflects. This categorisation generalises change across jurisdictions, institutions, localities and experiences. It is therefore vulnerable to critique as it might misrepresent changes in particular sites.

This analysis demonstrates that, whereas socialist legality sees law and legal institutions existing to give effect to a socialist conception of a Party-led state, the law-based state (or at least its socialist variant) envisages a shift from an instrumental role for law (and courts) to a situation where law exists to regulate social relations and where legal institutions are increasingly self-managed, although within the auspices of Party leadership. The law-based state does not posit state institutions 
as autonomous of Party influence, rather it reconfigures Party influence. The Party remains the dominant influence, mediated by an ancillary set of duties to the law. Yet, as we shall see, this remains more fluent in the abstract than it does in practice.

\section{RESOLUTION 8 AND LEGAL THEORY}

Returning to Resolution 8 , we see that the reforms affecting courts can be summarised as follows

- increasing the role of the Supreme People's Court in the management of lower courts

- giving the Supreme People's Court power to appoint judges

- increasing the technical competency of judges

- increasing the public's knowledge of the work of courts

- increasing the role of lawyers/prosecution in court advocacy

- investigating the role and function of the administrative court, family court, people's assessors, as well as of the death penalty, state sovereignty, legal practice and international cooperation.

The central tenet of Vietnamese jurisprudence (or political-legal theory) has moved from socialist legality to the emerging conception of the law-based state. The core feature of the law-based state is its attempt to characterise the law as a phenomenon that binds the state. The law, however, is always subject to interpretation and thus what is drawn upon to determine its meaning might be law or policy that has not yet been, or may never be, enacted.

In Vietnam, the notion of a law-based state does not sit alone, but is accompanied by other legal doctrines, in particular, collective mastery and democratic centralism, each of which, while dynamic, also affords continuity with Vietnam's legal history. Yet neither of these doctrines has been fundamentally revisited or rejected since the reconceptualising of the state as 'law-based'.

\section{COMMENT IN CLOSING}

Resolution 8 appears largely to give practical effect to recent Vietnamese theorising. Its most significant changes potentially enable the courts to manage their own staff, professional development and guidelines (Nicholson 2003). In other words, as a legal institution, the courts are uncoupled from the executive arm of the state and given autonomy to implement Party direction. This is evident in the Supreme People's Court's greater control over budgets and staff selection and the project of developing a trained, technically competent judiciary.

As noted in both Resolution 8 and the shift to law-based state, the Vietnamese leadership does not countenance a diminishing role for the Party. The Party retains a very tight grip on who will be appointed by the Supreme People's Court to lower courts (Nicholson and Nguyen Hung Quang, 2005). The requirements ensure that local and central branches of the Party vet all judicial candidates. Further, every 


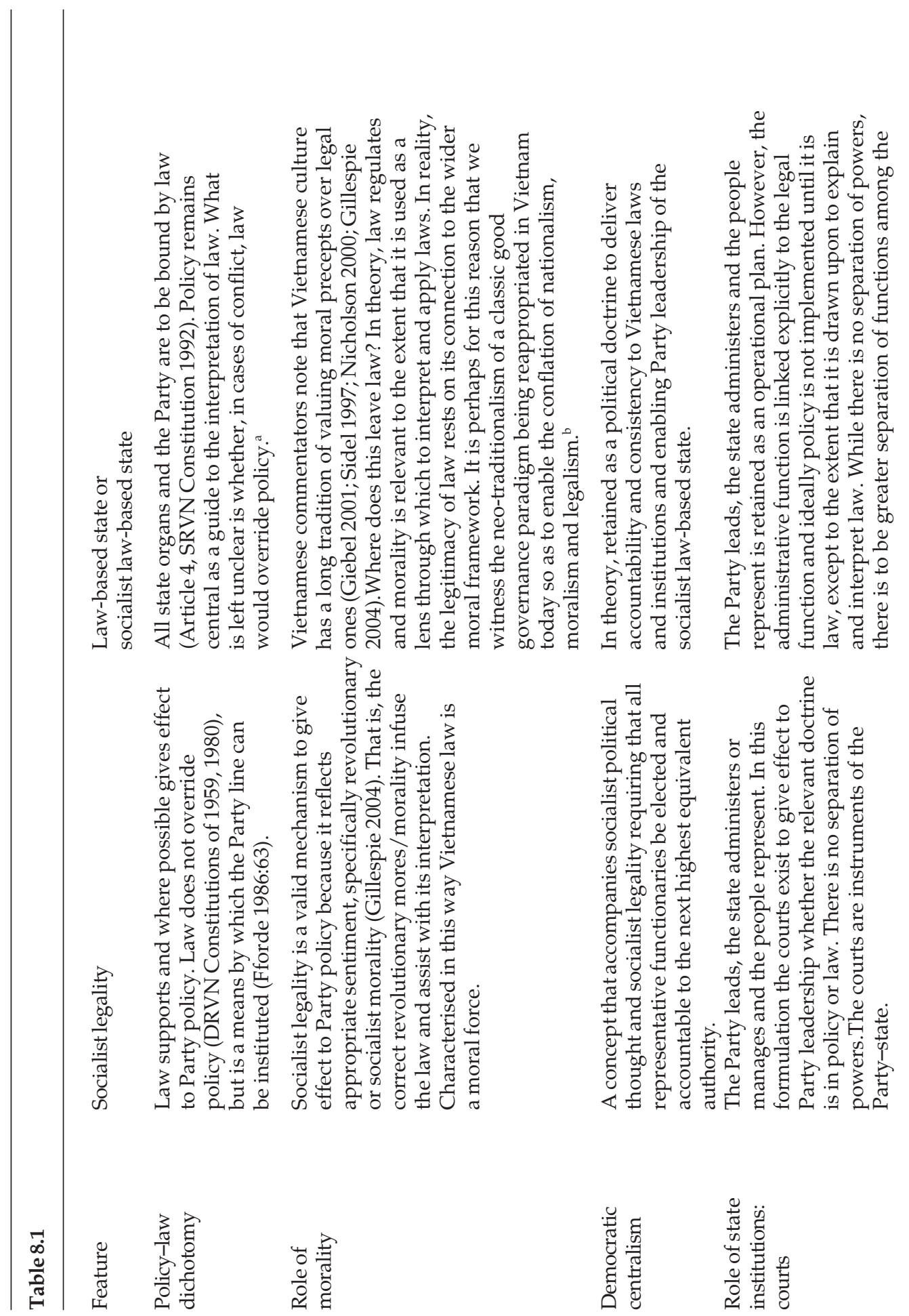



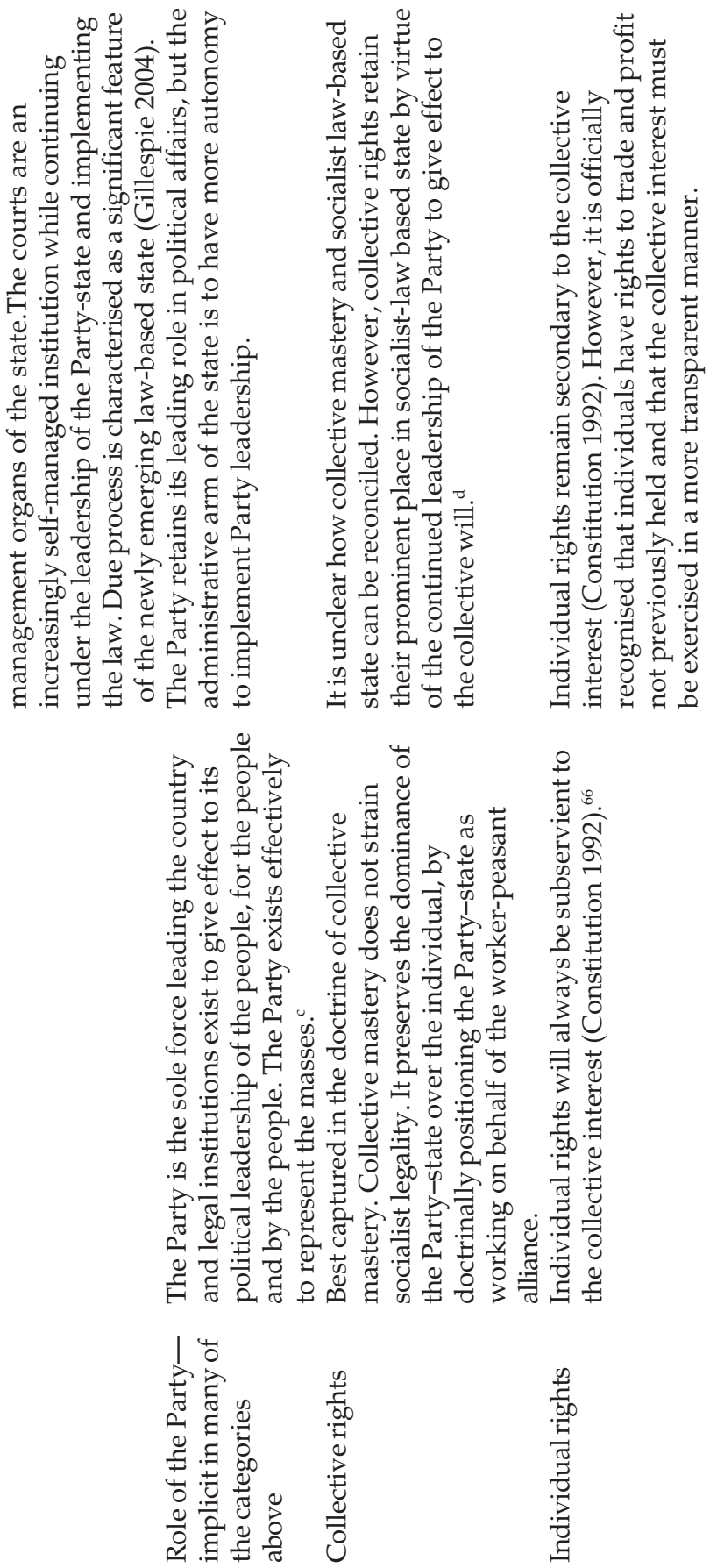

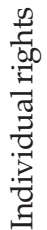

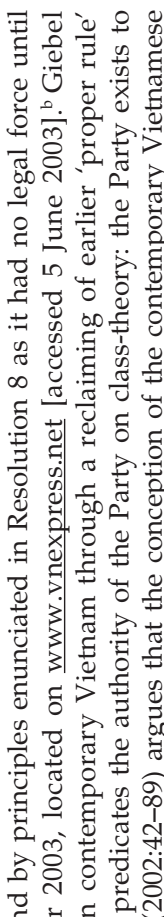

ฮั

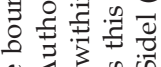
\& 450

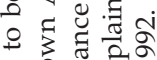

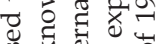

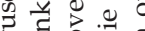

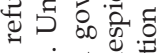

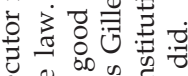

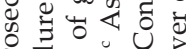
范 000 . 踪:

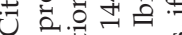

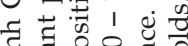

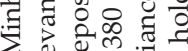

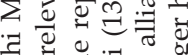
式焉焉䒕

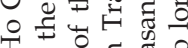
工

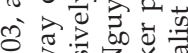

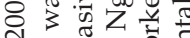

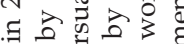
ণ

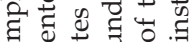
त्र

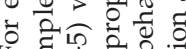
๘.

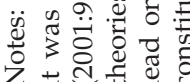


appointment is revisited every five years. Without security of tenure it is very unlikely that judges will ignore Party direction generally or in particular cases.

The areas that Resolution 8 nominates for further investigation indicate that the Party-state either does not have a comprehensive blueprint for legal change or wishes to see legal changes introduced incrementally. ${ }^{67}$ In particular, it is currently too difficult to reformulate the role of people's assessors and the Administrative Court in a state where the mass line and Party leadership have not been abandoned. In other words, the Party leadership is not prepared to remove lay representatives from trials (although they have disappeared from the Supreme People's Court) and radically expand the review of administrative decisions. Each of these reforms could potentially see the Party's leadership diminished.

By avoiding reforms to the system of people's assessors and administrative review, the leadership of the Party and its claims of representing the 'masses' via democratic centralism and collective mastery are left largely intact. This arguably reflects their connection with the socialist/collective and popular notions of justice. For example, the socialist state, having introduced people's assessors to democratise and popularise the law and the courts, may find it difficult to remove them. Therefore potential people's assessors reforms (such as better training or even abolition) have not yet been implemented despite criticism of the lack of technical competence by lawyers. Instead, their role is to be 'investigated'. In a similar vein, widening the scope of administrative review could threaten the leadership of the Party as it could enable challenges to the Party-bureaucracy's discretionary decision-making. Again, rather than challenge the leadership of the Party by expanding review of administrative action, it is left for future debate.

While the notion of law-based state is not entirely consistent with either democratic centralism or collective mastery, precisely because it envisages the Partystate being bound by law and not able to respond as directly as now to pressures and policies from the Party and state, this conflict has not been taken up by Resolution 8. Yet again, Resolution 8 appears consistent with Vietnamese theoretical understandings of law where this tension is not widely debated.

Finally, as we have seen, Resolution 8 specifically promotes the role of the lawyer in the emerging law-based state. The socialist law-based state implicitly requires a repositioning of lawyers as it is consistent with a move from political discretion to law-based decision-making. It appears on the face of it, however, that an active private legal profession could challenge the Party-state's hold on the synergies between Vietnamese legal theory and policy review. An activist group of lawyers could potentially push for legalisation of institutions and practices in Vietnam, which could fracture the delicate balance between socialist conceptions of law and justice and institutional renovation currently in place. Only time will tell whether the nascent Vietnamese legal profession will act as a catalyst for more dramatic legal change or whether they will work closely with the Party-state to reshape Vietnam's legal system further. The policy should be read as an ideological endorsement of incremental and cautious change. 
This chapter commenced by asking whether the latest Party policy statement on 'judicial reform' reflected contemporary Vietnamese legal theory. As we have seen, in the main it does. The orientation of Resolution 8 accords with the emerging doctrine of a law-based state. More particularly, we have seen that the policy direction for courts - that they be self-managed, bound by law and also implementing lawechoes the notion of a Vietnamese state based on law. At the same time, both the policy paper and the doctrine of 'law-based state' assume the continuing supremacy and leadership of the Communist Party of Vietnam. In conclusion, Resolution 8 appears largely consistent with Vietnamese jurisprudence. It reflects Vietnam's adoption of the socialist law-based state while containing the same ambiguities evident in legal theory about the role and place of the masses and Party-state leadership.

This chapter also raised a larger question at the outset; namely, the extent to which Vietnam has conceived of the role and place of law in post-doi moi Vietnam. While it is harder to answer this question solely on the basis of an analysis of one, albeit major, recent policy, it appears that the Party-state has adopted cautious incrementalism and experimentalism in its reshaping of law and legal institutions. Vietnamese pragmatism is once again evident.

\section{ACKNOWLEDGMENT}

The author gratefully acknowledges translation assistance by Nguyen Thi Ngoc Quynh, Masters Student in Applied Linguistics at the University of Melbourne in 2003.

\section{NOTES}

1 Law on Organisation of People's Courts, 2 April 2002 and Ordinance on Judges and Jurors of People's Courts, 11 October 2002. See also Inter-circular No. 05/TTLN of the Ministry of Justice and SPC, dated 15 October 1993, Providing Guidelines on Ordinance on People's Judges and Jurors 1993 and Resolution 131/2002/NQ- UBTVQH11 On Judges, People's Assessors and Prosecutors, dated 3 November 2002.

2 Comment made by conference participant Nguyen Chi Dung, at the Law and Governance: Socialist Transforming Vietnam conference, Melbourne, 13 June 2003.

3 This chapter will not follow the reforms affecting other court-related agencies such as the police or the procuracy.

4 The settlement of CPV policy would have involved circulation of drafts of the policy to relevant organs, including the heads of Party cells in law-related institutions. Once the document was settled, it would have been circulated to all relevant agencies and the membership of Party cells within these. This policy can also be purchased from the Party publisher and bookstalls.

5 Not only are the working conditions poor (for example, offices are too small) but the facilities are old.

6 As set out earlier, this chapter looks only at the policy's effect on court work, and not at its implications for other legal institutions such as the police, the investigators or the procuracy.

7 Real democracy is the literal translation of thuc su dan chu. In the Vietnamese context it connotes equal rights for individuals.

8 For a general discussion of the Vietnamese court system in the 1990s, see Quinn (2002) and Nicholson (2001).

9 Dung reminds us that Article 6 of the 1992 Socialist Republic of Vietnam (SRVN) Constitution gives the National Assembly and its Standing Committee supremacy. Further, Dung (2003) 
argues that this entails a reporting function to the National Assembly and the relevant People's Council.

10 See Directive No 10/2002/CT on the implementation of the Political Bureau's Resolution No. 8 for a general implementation plan.

11 Law on Organization of People's Courts, 2 April 2002; and Ordinance on Judges and Jurors of People's Courts, 11 October 2002. See also Inter-circular No. 05/TTLN of Ministry of Justice and SPC, dated 15 October 1993, Providing Guidelines on Ordinance on People's Judges and Jurors 1993; and Resolution 131/2002/NQ- UBTVQH11 On Judges, People's Assessors and Prosecutors, dated 3 November 2002.

12 See also Ordinance on Judges and Jurors of People's Courts, 11 October 2002; Inter-circular No. 05/TTLN of Ministry of Justice and SPC, dated 15 October 1993, Providing Guidelines on Ordinance on People's Judges and Jurors 1993; and Resolution 131/2002/NQ- UBTVQH11 On Judges, People's Assessors and Prosecutors, dated 3 November 2002.

13 In particular, implementing legislation has waived the requirement that judges have a Bachelor of Laws Degree.

14 Circular No. 01/2003/TTLT/TANDTC-BOP-BMV/UBTWMTTQVN Guiding the Implementation of a Number of Provisions of the Ordinance on Judges and Jurors of the Supreme People's Court, The Ministry of Defence, The Ministry of Justice, The Ministry of the Interior and The Vietnam Fatherland Front Central Committee, dated 1 April 2003 ('Circular 01'), Chapter III, Article 2, Step 3.

15 Step 4, Article 2, Chapter III, Circular 01.

${ }_{16}$ This position is clear in the legislation passed to give effect to this policy. In particular, judges seeking appointment need a letter of support from the Party Cell of the court to which they seek appointment and a Political Knowledge Certificate from the Central Political Training Institution.

17 Translation from Cong Bao, the Official Gazette, No. 25, of 5 June 2002.

18 Many parties bemoan the lack of equal treatment. For example, it has been explained to the author by a Ministry of Justice official that the great challenge to the enforcement of foreign arbitral awards in Vietnam is usually they are to be enforced against state-owned enterprises. Thus, courts charged with establishing the 'legality' of foreign awards do not treat the interests of the parties' 'equally'. State policy to protect state-owned enterprises (and the stability they bring through employment) is given priority by the courts. Interview by author, Hanoi, 11 October 2003.

19 Since 1959, when the Democratic Republic of Vietnam (DRVN) as it then was established its official court systems, mobile hearings have been a feature of court work (Nicholson 2000).

20 For example, the judgment resulting from the 1997 trial of Tran Thi Chieu and Bui Van Tham for corruption does not indicate the basis upon which either Chieu or Tham were found to have breached the Criminal Code. Judgment No. 233/HSST 22 February 1997 of the Hanoi People's Court.

${ }^{21}$ Neither do jury trials in common law systems record the evidentiary basis of the conviction.

2 See Judgment No. 233/HSST of the Hanoi People's Court, 22 February 1997.

23 The lack of reasons has several consequences. First, it is very hard for courts and lawyers to appeal or review cases when they are not able to understand the reasons behind judgments and particularly if they do not have access to the prosecution documents. Second, it is hard for higher courts to instruct lower courts on the basis of judgments alone. This then provokes a need for case summaries to be written and circulated, a need which has traditionally been met through publications in the Court's Journal and more recently by case summaries prepared for the sole purpose of transmitting how to adjudge cases. See Nicholson (2000) on the use of the court journal. On the use of case summaries in civil and economic cases, see Gillespie (2003).

24 Both lawyer Nguyen Hung Quang and legal journalist Nguyen Hien Quan (currently a doctoral student at the University of Melbourne) have pointed out to me that lawyers have played an adversarial role in the Nam Cam trial, reflecting an experiment by the state to allow advocates to test the evidence publicly in open court.

25 Changes to the regulation of lawyers are in fact reinforcing this distinction by requiring state lawyers not to work in private practice. Discussion with Pham Duy Nghia and Bui Bich Thi Lien in Canada, April 2003.

26 Gillespie notes that whether revolutionary thinking should dominate legal thinking was on the agenda in conferences before 1986, but that no decision was made to change the status quo during these earlier debates. 
27 It is commonly asserted that the Party continued to operate even after its official dissolution in 1945. This position is supported when Tran Thi Tuyet (1997:25) writes 'in fact it withdrew into secret'.

28 Statute of the Communist Party of Vietnam, 2001.

29 Conversation with lawyers in Hanoi over the period 1992-2002.

30 For example, the Supreme People's Court Journal over the period 1960-76 draws very little on Chinese jurisprudence while it borrows heavily from the USSR, devoting sections to translation of Soviet jurisprudential terms (Nicholson 2000). With the collapse of the Chinese legal system during the anti-Rightist campaign launched in 1957 and the Cultural Revolution (1966-76), Vietnam received little Chinese leadership on law and legal development during this period (see Leng 1967).

31 Shaun Malarney (1997) traces the continuities between Confucian and socialist ethics.

32 This discussion of the role and place of law after the Declaration of Independence in Vietnam until unification of the country in 1976 is drawn from Nicholson (2000).

33 This contrasts with the position in the USSR where during the early days of the revolution legal philosophers conceived of law withering away (Nicholson 2000).

34 Truong Trong Nghia similarly characterises Ho Chi Minh's attitude to law in 'The Rule of Law in Vietnam: Theory and Practice' available at http://www.mcpa.org. He argues Uncle Ho was committed to the Rule of Law. Laws were passed early in the life of the new regime. For example, in 1946 they passed laws to establish the Military Court with powers to try civilians and military figures for treason.

35 Here Boudarel is quoting from an editorial written by Nguyen Huu Dang (1956) in the fourth issue of Nhan Van.

36 Between 1953 and 1956 Vietnam introduced a land reform policy closely modelled on the land redistribution policies of China. See generally White (1981).

37 Nhan dan, 1956, Hanoi, 13 December; reprinted in Hoa Mai (ed) The Nhan Van Affair, pp. 161162. This material is cited by Turner (1975:158-9). Turner notes that the article was written by students of the Hanoi-based Nguyen Trai School at the instigation of the Vietnam Workers' Party.

38 Boudarel notes that five main players (Nguyen Huu Dang, Luu Thi Yen, Tran Thien Bao, Phan Tai and Le Nguyen Chi) were tried and that all received periods of imprisonment followed by a period of national indignity when they were not permitted to leave their homes.

39 This organising principle is also reflected in the 1959 Constitution and its inclusion in Article 4 was specifically referred to by Ho Chi Minh (1961:416) in his 'Report on the Draft Amended Constitution' to the National Assembly in 1959. Ginsbergs (1963:209) points out that the DRVN was the first communist state to include democratic centralism in its constitution. For a discussion of Soviet democratic centralism, see Butler (1983); Hazard (1969); Gryzbowski (1962); Ioffe (1985); Ioffe and Maggs (1983).

40 Article 10, Statute of the Vietnam Workers' Party, 1960. This legislation is referred to here, although it was not introduced until 1960, because it reflects the practices that emerged in the preceding years of the administration. In many cases, as we shall see, formal laws were introduced after a period in which that which was introduced had already been operative. See also Gainsborough (2003).

41 The Party ceased to exist between 1945 and 1951, but once reformed its membership comprised major office holders such as the president and prime minister (Ho Chi Minh) and ministers. For example, the Ministers of Defence and Foreign Affairs and the Commander in Chief of the Armed Forces were all Party members. See Fall (1956).

42 Ho Chi Minh (1994:119) also refers to Stalin's leading role in this regard citing Stalin's argument that 'close control' can help the Party to 'avoid many grave mistakes'.

43 Gillespie (2003) notes that this is the foundation of socialist democracy: where, borrowing from Lenin, the working class have to 'centralise power in their hands'.

44 Preamble, Statute of the Vietnam Workers' Party, 1960. Here the word 'masses' is used because of its use in the Statute. However, it will also be used throughout this chapter when a reference is made to Vietnamese people who were members of the agricultural or labouring classes. It is an overtly political word used throughout Vietnamese writing to refer to the previously oppressed, but soon to be liberated, classes of Vietnamese society. Use of the word assists the reader to understand the militant political milieu in which this story was unfolding. 
45 The understanding that law had a role to play in the revolution seems to have been spoken about by lawyers and politicians, but it is hard to ascertain how it was more generally debated.

46 Compare this with the situation in the Soviet Union, Nicholson (2000).

47 Editors, Justice Journal, Vol. 1, 1964, pp. 1-4 (in Vietnamese).

48 In particular, Sidel cites Vu Dinh Hoe (previously Minister for Justice, a non-communist lawyer) and Tran Cong Truong as leading figures campaigning for legal reform.

49 Here law is used to refer to economic principles ('objective economic laws').

50 The tone of the article is legalistic rather than critical. This distinguishes it from the articles published in Nhan Van (Humanity) discussed previously.

${ }^{51}$ As mentioned previously, Sidel describes the activities of the Legal Studies Group in the 1960s and early 1970s, pointing out that legal scholars debated the role of law throughout the period.

52 The other three tenets were 'good at guiding production work and fighting'; 'good at caring for the masses and integration with them'; and 'good at strengthening the work of the Party'.

53 The ensuing discussion is drawn from Nicholson (2000). The DRVN officially established a 'court system', as opposed to a system of regionally administered courts, in 1959.

54 Chief Judge of the Supreme People's Court (1967) Editors, Conference Summary, p. 3 [in Vietnamese].

55 Chief Judge of the Supreme People's Court (1967) Editors, Conference Summary, p. 3 [in Vietnamese].

56 Chief Judge of the Supreme People's Court (1968), Conference Summary, p. 25 [in Vietnamese].

57 For example: Unsigned Article (1961:4). See also comments made by Ho Chi Minh (1924:772), as cited in Turner (1975:137).

58 Before proceeding, I wish to acknowledge the work of John Gillespie in mapping contemporary Vietnamese socialist legal thinking. Much of the Vietnamese legal theory relied upon in this section is directly drawn from his more recent, and as yet unpublished, work.

59 Gillespie (2003) notes that this is the foundation of socialist democracy-according to Lenin's thought, the working class have to 'centralise power in their hands'.

60 For analysis of the Northern Vietnamese Constitutions, see Duiker (1992); Marr (1995); Nicholson (1999).

61 The 1976 unification Constitution is the most explicitly socialist of all Vietnam's Constitutions, as evidenced by its preamble. See also Nicholson (1999); and John Gillespie's chapter in this publication.

62 John Gillespie's chapter in this publication.

63 Article 4, SRVN Constitution 1992.

${ }^{64}$ Article 4, SRVN Constitution 1992, as amended in 2001.

65 Article 4, SRVN Constitution 1992, as amended in 2001.

${ }_{60}$ Certainly this is suggested by Resolution 8 .

67 This comment is not intended to detract from the very great pace of legal change in Vietnam since the adoption of the renovation (doi moi) policy. In interviews by the author in June 2005, it was suggested that the Politburo has approved the legal reform strategy. It is yet to be made public.

\section{REFERENCES}

Beresford, M., 1997. 'Vietnam: the transition from central planning', in G. Rodan, K. Hewison and R. Robison (eds), The Political Economy of South-East Asia: conflicts, crises and change, Oxford University Press, Melbourne:206-32.

Bergling, P., 1999. Legal Reform and Private Enterprise: the Vietnamese experience, Volume 1, Umea Studies In Law, Department of Law, Umea University, Sweden.

Bo Tu Phap (Justice Ministry), 1957. Tap Luat Le ve Tu-Phap [Collection of Laws about Justice], Ministry of Justice Publishing House, Hanoi.

Boudarel, G., 1990. 'Intellectual dissidence in the 1950s: the Nhan Van Giai Pham affair', The Vietnam Forum, 13:154-74. 
Butler, W.E., 1983. Soviet Law, Butterworths, London.

Chao-chuan Leng, 1967. Justice in Communist China, Oceana Publications Inc., New York.

Clark, D., 1999. 'The many meanings of the rule of law', in K. Jayasuriya (ed.), Law, Capitalism and Power in Asia, Routledge, London:28-44.

Dang Quang Phuong, 1996. 'Vai net ve qua trinh hinh thanh va phat trien cua Toa an nhan dan, [Some sketches of the establishment and development of the People's Court]', Thuat Chung Ket Qua Chinh Nghien Cuu De Tai (Final Abstract about Principal Research), Unpublished work of the Supreme People's Court, Hanoi.

Duiker, W., 1992. 'The constitutional system of the Socialist Republic of Vietnam', in L.W. Beer (ed.), Constitutional Systems of Late Twentieth Century Asia, University of Washington Press, Seattle:331-61.

Fall, B., 1956. The Viet Minh Regime Government Administration in the Democratic Republic of Vietnam, Greenwood Press Publishers, Connecticut.

Fforde, A., 1986. 'The unimplementability of policy and the notion of law in Vietnamese communist thought', Southeast Asian Journal of Social Science, 62(1):60 70.

- and de Vylder, S., 1996. From Plan to Market: the economic transition in Vietnam, Westview Press, Colorado.

Gainsborough, M., 2003. Changing Political Economy of Vietnam: the case of Ho Chi Minh City, Routledge Curzon, London and New York.

Giebel, C., 2001. 'Museum-shrine: revolution and its tutelary spirit in the village of My Hoa Hung', in Hue-Tam Ho Tai (ed.), The Country of Memory: remaking the past in late Socialist Vietnam, University of California Press, Berkeley:77-105.

Gillespie, J., 2001a. 'Self-interest and ideology: bureaucratic corruption in Vietnam', Australian Journal of Asian Law, 3(1):1-36.

_ 2001b. 'Globalisation and legal transplantation: lessons from the past', Deakin Law Review, 6(2):286-311.

- 2002. 'The political-legal culture of anti-corruption reforms in Vietnam', in T. Lindsey (ed.), Corruption in Asia: rethinking the governance paradigm, The Federation Press, Sydney:167-200.

__ , 2003. Extra-constitutional Law-making: Vietnam's unacknowledged legislators, Paper presented at the conference Mapping Vietnam's Legal Culture: where is Vietnam going to?, University of Victoria, Victoria, Canada, 27-29 March.

- , 2004. 'Concept of law in Vietnam: transforming statist socialism', in R. Peerenboom (ed.), Asian Discourses of Rule of Law, Routledge, London:146-82.

Ginsbergs, G., 1963. 'Local government and administration in the DRVN since 1954 (Part 2)', The China Quarterly, 14:195-210.

Gryzbowski, K., 1962. Soviet Legal Institutions, Doctrines and Social Functions, University of Michigan Press, Ann Arbor.

Hazard, J.N., 1969. Communist and Their Law, University of Chicago Press, Chicago. 
Ho Chi Minh, 1924. 'The martyrdom of the negro, American lynch-justice', International Press Correspondence (Moscow), 4(60):772, in R.F. Turner, 1975. Vietnamese Communism: its origins and development, Hoover Institution Press, Stanford:136-37.

— 1961. Selected Works, Volume II, Foreign Languages Publishing House, Hanoi.

— 1994. 'Political report at the second national congress of the Vietnam workers' party', in Ho Chi Minh Selected Writings, Revised Edition, Gioi Publishers, Hanoi:101-29.

Hooker, M.B., 1978. A Concise Legal History of South-East Asia, Butterworths, Singapore.

Huynh Kim Khanh, 1982. Vietnamese Communism 1925-1945, Cornell University Press, Ithaca, New York.

Ioffe, O.S., 1985. Soviet Law and Soviet Reality, Martinus Nijhoff, Dordrecht. and Maggs, P.B., 1983. Soviet Law in Theory and Practice, Oceana Publications Inc, Dobbs Ferry, New York.

Klein, W.C. and Weiner, M., 1959. 'North Vietnam' in G. McTurnan Kahin (ed.), Governments and Politics of Southeast Asia, Cornell University Press, Ithaca, New York.

Le Duan, 1994. 'Some problems of cadres and organization in socialist revolution in 1973', in Le Duan Selected Writings, Gioi Publishers, Hanoi:410-76.

Le Kim Que, 1974. 'The People's Courts', in anonymous, An Outline of the Institutions of the Democratic Republic of Vietnam, Gioi Publishers, Hanoi.

Leng, Chao-chuan, 1967. Justice in Communist China, Oceana Publications Inc., New York.

Luu Tien Dung, 2003. Judicial Independence in Transitional Countries, Governance Centre, Oslo.

Malarney, S.K., 1997. 'Culture, virtue and political transformation in contemporary Northern Viet Nam', The Journal of Asian Studies, 54(4):899-920.

Marr, D., 1995. 'Ho Chi Minh's independence declaration', in K.W. Taylor and J.K. Whitmore (eds), Essays Into Vietnamese Pasts, Studies on Southeast Asia, Cornell University, Ithaca, New York:221-31.

McMillan, J. and Woodruff, C., 1999. 'Dispute prevention without courts in Vietnam', Journal of Law, Economics and Organization, 15(3):637-58.

Ngo Van Thanh, 1996. 'Chuyen de Chuc Nang va vai tro cua toa an quan su trong cac thoi ky cua cach mang Viet Nam [The role and function of the Military Courts in the stages of the Vietnamese revolution]', Tong Thuat Chung Ket Qua Chinh Nghien Cuu De Tai [Final Abstract about Principal Research], Unpublished work of the Supreme People's Court, Hanoi.

Nguyen Ngoc Minh, 1985. 'Building a new type state in Vietnam', Vietnam Social Sciences, 1:51-65.

Nguyen Nhu Phat, 1997. 'The role of law during the formation of a market-driven mechanism in Vietnam', in J. Gillespie (ed.), Commercial Legal Development in Vietnam: Vietnamese and foreign commentaries, Butterworths, Singapore:397-412. 
Nguyen Nham, 1997. Foreign Broadcast Information Service East Asia, 97-203, 23 June:3.

Nguyen Van Hien, 2001. 'Tieu chuan tham phan-thuc trang va nhung yeu cau dat ra trong thoi ky moi [Judicial criteria-current situation and requirements for new era]', People's Court Journal, 4:2-6.

Nicholson, P., 1999. 'Vietnamese legal institutions in comparative perspective: contemporary constitutions and courts considered', in K. Jayasuriya (ed.), Law, Capitalism and Power in Asia, Routledge, London:300-29.

— 2000. Borrowing Court Systems: the experience of the DRVN 1945-76, PhD thesis, University of Melbourne, Melbourne.

- 2001. 'Judicial independence and the rule of law: the Vietnam court experience', Australian Journal of Asian Law, 3(1):37-58.

- 2003. Vietnamese Court Reform: constancy and change in the contemporary period, Conference paper presented at Mapping Vietnam's Legal Culture, University of Victoria, Canada, 28 March

— and Nguyen Hung Quang, 2005. 'The Vietnamese judiciary: the politics of appointment and promotion', Pacific Rim Law and Policy Journal, 14(1):1-34.

Pham Van Bach, 1961a. 'Bao Cao cua Toa an nhan dan toi cao tai ky hop thu hai cua Quoc hoi Khoa II [The report of the Supreme People's Court to the second session of the National Assembly's second legislature]', Tap San Tu Phap, 6:1-12.

-, 1961b. 'Vai nhan thuc ve nhiem vu cua Toa An Nhan Dan trong Ke Hoach Nha Nuoc 5 Nam: 1961-1965 [Several points about the responsibilities of the People's Courts in the state five-year plan 1961-1965]', Tap San Tu Phap, 1:1-8.

__ 1964. ‘Bao Cao ve su tich cuc cho nam 1963 va chieu phua cho nam 1964 [Report on the activities of the year 1963 and directions for the year 1964 of the People's Courts]', Annex to Tap San Tu Phap, Annexure to No. 5.

Quinn, B.J.M., 2002. 'Legal reform and its context in Vietnam', Columbia Journal of Asian Law, 15(2):219-91.

Sidel, M., 1997a. 'Some preliminary thoughts in contending approaches to law in Vietnam, 1954-1975', paper presented at the Association for Asian Studies Conference, March (unpublished).

—_, 1997b. 'Vietnam', in P-L Tan (ed.), Asian Legal Systems, Butterworths, Sydney:356-89.

_-1998. Chinese Legal Influences on Vietnamese Legal Development since 1986, Paper presented at the Law and the Chinese Outside Asia Conference, Canberra, 5-6 July.

— 2002. 'Analytical models for understanding constitutions and constitutional dialogue in socialist transitional states: re-interpreting constitutional dialogue in Vietnam', Singapore Journal of International \& Comparative Law, 6(1):42-89.

Thayer, C., 2002. Recent Political Developments: Vietnam in 2002, paper presented at the Vietnam Update, The Australian National University, Canberra, 28-29 November. 
Tran Thi Tuyet, 1997. 'Vietnamese state structures and law during the anti-French colonialist war', Vietnam Legal Forum, 25(1):25-26.

Truong Chinh, 1994. Truong Chinh Selected Writings, Hanoi, Revised Edition, Gioi Publishers, Hanoi.

Truong Tan Phat, 1964. Nhan dan, 26 March:2.

Truong Trong Nghia 'The Rule of Law in Vietnam: theory and practice'. Available online at http:/ / www.idlo.int/texts/IDLI/mis6094.pdf.

Turner, R.F. (ed.), 1975. Vietnamese Communism: its origins and development, Hoover Institution Press, Stanford.

Unnamed Editors, 1996. 'Dat van De [Presentation]', Thuat Chung Ket Qua Chinh Nghien Cuu De Tai [Final Abstract about Principal Research], Unpublished work of the Supreme People's Court, Hanoi.

Unknown Author, 2003. '2 cong to vien tranh luan voi hon 70 luat su [2 Prosecutors Argue with More than 70 Lawyers]', Nguoi Lao Dong [Labour Men], 16 February.

Unsigned Article, 1961. Nhan dan, 18 May:4.

Van Arkadie, B. and Mallon, R., 2003. Viet Nam: a transition tiger?, Asia Pacific Press, Canberra.

Vu Dinh Hoe, 1995. 'Les quatres constitutions du Viet Nam', Vietnamese Law Journal, 2:24-28.

Weggel, O., 1986. 'The Vietnamese Communist Party and its status under law', in D.A. Loeber, D.D. Barry, J.M. Feldbrugge, G. Ginsbergs and P.B. Maggs (eds), Ruling Communist Parties and their Status under Law, M. Nijhoff, Dordrecht, Boston:411-19.

White, C., 1981. Agrarian Reform and National Liberation in the Vietnamese Revolution: 1920-1957, PhD thesis, Faculty of the Graduate School, Cornell University, Ithaca, New York. 